\title{
Does Knowledge Sharing Pay? An MNC Subsidiary Perspective on Knowledge Outflows
}

\author{
Mahnke, Volker; Pedersen, Torben; Venzin, Markus
}

Document Version

Final published version

Publication date:

2006

\section{License \\ CC BY-NC-ND}

Citation for published version (APA):

Mahnke, V., Pedersen, T., \& Venzin, M. (2006). Does Knowledge Sharing Pay? An MNC Subsidiary Perspective on Knowledge Outflows. Center for Strategic Management and Globalization. SMG Working Paper No. 3/2006

Link to publication in CBS Research Portal

\section{General rights}

Copyright and moral rights for the publications made accessible in the public portal are retained by the authors and/or other copyright owners and it is a condition of accessing publications that users recognise and abide by the legal requirements associated with these rights.

Take down policy

If you believe that this document breaches copyright please contact us (research.lib@cbs.dk) providing details, and we will remove access to the work immediately and investigate your claim. 


\title{
Does Knowledge Sharing Pay? An MNC Subsidiary Perspective on Knowledge Outflows
}

\author{
Volker Mahnke \\ Torben Pedersen \\ Markus Venzin \\ SMG WP 3/2006
}

January 2006 
SMG Working Paper No. 3/2006

January 2006

ISBN: 87-91815-19-3

Center for Strategic Management and Globalization Copenhagen Business School

Porcelænshaven 24

2000 Frederiksberg

Denmark

www.cbs.dk/smg 


\title{
Does Knowledge Sharing Pay? An MNC Subsidiary Perspective on Knowledge Outflows
}

\author{
Volker Mahnke \\ Department of Informatics \\ Copenhagen Business School \\ Torben Pedersen \\ Center for Strategy and Globalization \\ Copenhagen Business School \\ Markus Venzin \\ Department of Strategy and Entrepreneurship \\ Università Luigi Bocconi
}

Version: November 6,2005

\begin{abstract}
This empirical paper explores knowledge outflow from MNC subsidiaries and its impact on the MNC performance. We develop and test hypotheses derived from literature on MNC knowledge flows integrated with the perspective of knowledge-creating, self-interested MNC subsidiaries. The hypotheses are developed using a simultaneous equation model applied to a unique dataset encompassing a German MNC, HeidelbergCement. Enablers and impediments of knowledge outflows are assessed in order to explain why subsidiaries share their knowledge with other MNC units. Implications are examined by studying the link between knowledge outflows and subsidiary performance. Our findings suggest that knowledge outflows increase a subsidiary's performance only up to a certain point and that too much knowledge sharing may be detrimental to the contributing subsidiary's performance.
\end{abstract}




\section{INTRODUCTION}

Knowledge transfer among subsidiaries provides opportunities to improve an MNC's overall performance (Bartlett and Ghoshal 1989; Kogut and Zander 1992; Szulanski 1996; Tsai and Ghoshal 1998; Gupta and Govindarajan 2000; Foss and Pedersen 2002). However, only a few studies empirically examine knowledge flows between subsidiaries to determine the effect of various antecedents on knowledge sharing in MNCs (Gupta and Govindarajan 2000; Hansen 1999; Holm and Pedersen 2000; Minbaeva et al. 2003). The literature suggests that subsidiaries benefit from knowledge inflows to a certain degree, which is determined by the receiving unit's absorptive capacity (Cohen and Levinthal 1990; Tsai and Ghoshal 1998), the ability and motivation of subsidiary employees to use received knowledge (Minbaeva et al. 2003; Foss and Pedersen 2002), the type of knowledge transferred (Kogut and Zander 1993), and the presence of communication channels (Daft and Lengel 1986). In extension of these studies, this paper examines the antecedents and performance effects of knowledge outflows. While most previous work on this subject has looked at knowledge flows from the perspective of the receiving unit, this paper takes the perspective of the contributing subsidiary - the subsidiary that shares its knowledge with other MNC units. This approach allows us to study both the reasons why the contributing subsidiary shares its knowledge, and the performance effect of knowledge sharing. Our key questions are: Why do subsidiaries share their knowledge with other MNC units? and How does knowledge outflow affect a contributing subsidiary's performance?

The issue of why subsidiaries share their knowledge has been studied on the individual level (see Cabrera and Cabrera 2002). In those studies, knowledge sharing is conceptualized as a social dilemma in which individual rationality might lead to collective irrationality. However, to our knowledge there is no study exploring this issue within an MNC context to analyze the motivation of subsidiaries to share their knowledge with others. 
Earlier studies on knowledge-sharing in the MNC usually focus on antecedents of knowledge sharing and assess the level of shared knowledge from the perspective of the receiving unit. While other studies just take subsidiaries' willingness to share their knowledge with others as granted, the starting point for the current paper is that the motivation to engage in knowledge outflow is not a given. For a contributing subsidiary, sharing knowledge with other units may require time and resources, particularly if that knowledge is tacit and sticky, or if faceto-face interaction is required for knowledge sharing (Von Hippel and Tyre 1994). In addition, given inter-subsidiary competition for reputation and resources, a contributing subsidiary's managers might fear that other units will exploit shared knowledge, and therefore limit their engagement accordingly (Foss and Mahnke 2003; Mudambi and Navarra 2004). Applying the perspective of the contributing subsidiary provides insights into the enablers as well as the impediments of knowledge sharing. This also makes it possible to examine and endogenously explain why subsidiaries share their knowledge with other MNC units.

With a few recent exceptions (such as Andersson et al. 2002; Mahnke et al. 2005), the relation between $\mathrm{MNC}$ knowledge flows and subsidiary performance remains largely an assertion and has not, for the most part, been empirically corroborated. The current paper offers an analysis of effects on the contributing subsidiary's performance, as opposed to overall MNC performance or the performance of the receiving unit, and proposes that it may not always be in the best interest of a contributing unit to engage in knowledge outflows (Szulanski 1996; Gupta and Govindarajan 2000). In fact, we find the relationship between knowledge sharing and performance to be an inverted, U-shaped relation, indicating that some knowledge sharing will improve the contributing subsidiary's performance, while too much knowledge sharing will have a negative impact on performance, as the cost of knowledge sharing exceed the benefits. 
The contribution of this paper is four-fold: 1) While prior studies have restricted their analyses to antecedents of knowledge flows and neglected performance implications, this paper includes a direct test of the performance implications of knowledge outflows. 2) This paper explores the perspective of the contributing subsidiary, and 3) it introduces a model that treats a subsidiary's motivation to engage in knowledge outflow as an endogenous construct determined by both enablers and impediments. Finally, 4) a unique data-set of individual perceptions of knowledge processes obtained from a single MNC - HeidelbergCement - is applied to test the entire model including antecedents (enablers and impediments), the intermediary steps (knowledge outflow) and the final outcome (subsidiary performance).

\section{SUBSIDIARY OBJECTIVES: SELF-INTEREST VS. MINC CITIZENSHIP}

Recognizing the increasing role of MNC subsidiaries in knowledge creation, a number of authors report that subsidiary struggle $\mathrm{s}$ to bring locally-developed ideas and strategic drive to bear at the overall MNC level (Forsgren 1997; Rugman and Verbeke 2002). In this paper, we are concerned with antecedents to a subsidiary's knowledge outflow. However, we do not take the willingness of subsidiaries to share their knowledge as a sign that the subsidiaries are good MNC citizens, but seek to explain this willingness through a contributing subsidiary's self-interest.

Rather than restricting subsidiaries to the exploitation of knowledge developed in the MNC's home base, MNCs have granted their subsidiaries mandates to assume geographic and product responsibilities to a large extent (see Frost 2001). Subsidiary roles within the MNC have shifted from home-base exploiting to home-base augmenting sites (Kuemmerle 1999), where knowledge is created in either centres of excellence (Holm and Pedersen 2000) or regional innovation centres (Asakawa and Lehrer 2003). Expanded subsidiary roles within the MNCs learning network enhances the overall learning and capability development of the MNC (Bartlett 
and Ghoshal 1989; Birkinshaw and Morisson 1995). At the same time, however, changing subsidiary roles are accompanied by changing power relations in terms of the exchange of resources and knowledge between subsidiaries and headquarter (Asakawa 2001; Ferner et. al. 2004; Mudambi and Navarra 2004).

Decision rights regarding the use of physical and financial resources remain 'loaned' from MCN headquarters, and are not 'owned' by the subsidiary (Foss and Foss 2002). However, decision rights with regards to knowledge outflows are hard for headquarters to control and, accordingly, knowledge sharing is hard to enforce. Therefore, subsidiaries might have substantial discretion over knowledge outflows when it comes to knowledge developed in a particular subsidiary location (see Mudambi and Navarra 2004). Thus, Holm and Pedersen (2000) suggest organization within the modern MNC might be viewed as a political game, where power and knowledge is increasingly distributed, and the clear hierarchical line of command, where knowledge and power are concentrated at the corporate headquarter, is disappearing. If control of key knowledge shifts in favor of subsidiaries, the issues of why subsidiaries contribute to the MNC through their knowledge outflows despite obvious impediments, and how alternative levels of knowledge outflows contribute to a subsidiary's performance become all the more important.

For example, if a subsidiary is managed as a profit centre in order to keep the costs of performance monitoring and evaluation low, subsidiary autonomy is crucial (Williamson 1975). However, this may make a high degree of inter-subsidiary coordination and knowledge sharing detrimental to profit maximization within a focal subsidiary. Therefore, some authors recommend socialization and normative control to encourage good $\mathrm{MNC}$ citizen behavior and to stimulate knowledge sharing (Ouchi 1982; Bartlett and Ghoshal 1989; Gupta and Govindarajan 1991, 2000). However, as long as financial performance measures are used to evaluate subsidiary managers, socialization and normative control may only encourage inter-subsidiary knowledge 
sharing to a limited extent, and encouragement of knowledge sharing remains, at least in part, an inconceivable way to foster the commitment of contributing subsidiaries (Kreps 1990; Foss 2003).

Finally, if knowledge is dispersed in the $\mathrm{MNC}$, and knowledge gaps between the headquarters and its subsidiaries occur, the strategic alignment of subsidiary management becomes complicated (Mahnke and Venzin 2003). While the MNC head office may seek to directly encourage the sharing of crucial knowledge, large knowledge gaps between headquarter and subsidiaries might lead to ill-directed 'selective interventions' (Williamson 1996; Foss 2003), which reduces a subsidiary managers' autonomy as well as the reliability of the subsidiary profits as a performance measure (Holmström 1979). In addition, frequent intervention by headquarter invites subsidiary managers to engage in lobbying, which can raise the overall bargaining costs within the MNC (Milgrom and Roberts 1988). In sum, subsidiaries can be expected to maximize their own performance when engaging in knowledge sharing activities, which might be at the expense of the $\mathrm{MNC}$ as a whole.

\section{DETERMINANTS OF SUBSIDIARY KNOWLEDGE OUTFLOW}

From a subsidiary perspective, one can ask the following question: If valuable knowledge is a source of subsidiary bargaining power and there are impediments to knowledge sharing, why would a subsidiary share its knowledge with other units? We argue that knowledge outflows decrease given a greater degree of tacitness in the subsidiary's knowledge (Polanyi 1966; Kogut and Zander 1992; Pedersen et al. 2003), a greater fear of opportunistic rent appropriation by the receiving unit (Williamson 1996; Mudambi and Navarra 2004), or a lack of access to appropriate communication channels (e.g. Ghoshal et al. 1994; Gupta and Govindarajan 2000). On the other hand, subsidiaries might increase their knowledge outflows when they expect to benefit from 
knowledge inflows from other subsidiaries. In that case, the credit assignment problems are solved by providing such incentives as acknowledgement and visibility (Foss and Mahnke 2003; Mahnke and Venzin 2003). In sum, both impediments, which are expected to decrease knowledge outflows, and enabling factors, which are expected to increase knowledge outflows, are at play.

\section{Impediments to knowledge outflows}

As subsidiaries have different interests, budgets, and goals, knowledge outflows from an MNC subsidiary may be constrained due to fear of loosing a superior bargaining position (Forsgren 1997), or a lack of compensation for efforts associated with knowledge outflows (Szulanski 2003). Also, knowledge shared with other subsidiaries might be opportunistically exploited (Williamson 1996), as occurs when a subsidiary "free-rides" on others' knowledge development efforts, takes undeserved credit, or misuses knowledge to lobby top management. Accordingly, we propose the following hypothesis:

Hla: The greater the fear of opportunism, the lower the knowledge outflow from the focal subsidiary.

In addition, the resources and effort required by subsidiaries for the generation of knowledge outflows depend on the type of knowledge involved. For example, Forsgren (1997) notes that the more subsidiary knowledge creation is specific to the local context, the greater the difficulty in sharing that knowledge. By implication, the more location-specific a subsidiary's knowledge is, the less it will be inclined (and asked) to share it, as the effort of providing the knowledge is too time-consuming and costly. When knowledge-sharing processes concern tacit 
knowledge that is signified by substantial causal ambiguity and uncertainty (Simonin 1999), it requires time-consuming personal interaction (Nonaka and Takeuchi 1995; Werr and Stjernberg 2003). As a consequence, we propose:

$H 1 b$. The more a subsidiary's knowledge is tacit, the lower the knowledge outflow from the focal subsidiary.

Since transferring tacit knowledge is a complicated task, subsidiary managers may decide to codify knowledge and standardize knowledge exchange situations. These codification processes, however, are time consuming and, accordingly, may discourage a focal subsidiary's knowledge outflow (Pedersen et al. 2003). As Cohen and Foray (1997:595) note, codification of knowledge is a costly process and includes "model building, language creation and the writing of messages." These processes are performed, in practice, through brainstorming sessions, team discussions, and the exchange and writing of thoughts (Zollo and Winter 2002). Even if knowledge is codified, the ease of sharing it with other units depends on the availability and access of appropriate communication channels (Daft and Lengel 1986; Gupta and Govindarajan 2000; Pedersen et. al. 2003). If appropriate communication channels are not available, non-trivial set-up costs might be incurred, including costs arising from technology investments, software, consultancy fees, and time required of managers and other employees. Therefore, we propose the following hypothesis:

Hlc: The less a subsidiary can use appropriate communication channels, the lower the knowledge outflow from the focal subsidiary.

\section{Enablers of knowledge outflows}


While there are impediments to a focal subsidiary's knowledge outflow that discourage the sharing of knowledge even if it would benefit the $\mathrm{MNC}$ as a whole, there are several reasons that knowledge outflows are in the interest of the sharing subsidiary. For example, given the norms of reciprocity, a contributing subsidiary that is highly involved in sharing its knowledge with others will also be an active recipient of knowledge from other units (Kim and Mauborgne 1998). This builds on the argument that knowledge flows follow existing channels of communication. A subsidiary that frequently shares knowledge with its peers becomes part of the "in crowd" and is more likely to know which units have knowledge it needs. It also receives inflows of knowledge in return for its own knowledge outflows. However, this will only enhance innovation if the subsidiary maintains enough capacity to absorb external knowledge (Tsai and Ghoshal 1998). In addition, knowledge inflows from other subsidiaries are an important part of a focal subsidiary's learning process through which new opportunities are discovered (Tsai and Ghoshal 1998), absorptive capacity is augmented (Cohen and Levinthal 1990; Zahra and George 2002), and new competences may be developed by blending existing knowledge with new knowledge (Foss and Pedersen 2002). Therefore, we expect that:

H2a: The greater the knowledge inflow from other MNC units, the greater the knowledge outflow from the focal subsidiary.

Moreover, when subsidiary employees' knowledge-sharing behavior can be specified, providing explicit informal acknowledgements can increase motivation, in particular if explicit acknowledgement acts as a complement rather than as a substitute for intrinsic motivation (Frey 1997; Laursen and Mahnke 2001; Foss and Mahnke 2003). Informal acknowledgement may help intrinsic motivation without incurring the negative effects of misdirected extrinsic rewards and solves the credit assignment problem that would otherwise hamper knowledge outflows from a focal subsidiary. Benefits provided by headquarters and by other MNC units, such as 
acknowledgement and visibility, positively influence a subsidiary's knowledge outflow. Therefore, we propose:

$H 2 b$. The greater the acknowledgement from other MNC units, the greater the knowledge outflow from the focal subsidiary.

\section{PERFORMANCE IMPLICATIONS OF KNOWLEDGE OUTFLOWS}

It is argued here that while the focal subsidiary's decision on knowledge sharing is determined by enablers and impediments, the actual act of engaging in knowledge sharing has implications for subsidiary performance. Knowledge outflows incur costs and benefits, thereby affecting subsidiary performance.

Sharing knowledge will often require interaction and meetings between different subsidiary employees, interactions which could otherwise be used for a subsidiary's internal business and development activities (Pedersen et al. 2003). Thus, the opportunity costs of knowledge outflows might be substantial, especially when key subsidiary experts use their scarce time to disseminate knowledge instead of developing new competences or solving problems for the focal subsidiary (Forsgren et al. 2000). For whatever reason, knowledge outflows may become so taxing for a focal subsidiary that they encounter internal resource constraints, which may diminish and eventually crowd out a subsidiary's own knowledge development. If, as a result, the absorptive capacity of the focal subsidiary decreases (Cohen and Levinthal 1990), knowledge inflows from other subsidiaries remain unused. Costs then increase while benefits decrease as a result of the subsidiary's over-extension in knowledge sharing.

In addition, as the amount of knowledge sharing increases, subsidiaries have to codify increasingly tacit knowledge. For example, while sharing available explicit knowledge with other subsidiaries may suffice in the beginning, the sharing of increasingly tacit knowledge will 
increase marginal codification and sharing costs. Although codification processes have benefits in terms of learning about the contributing subsidiary's processes (Nelson and Winter 1982), such learning might be subject to diminishing returns.

Moreover, while knowledge inflows from other MNC units may encourage a subsidiary's knowledge outflow because they trigger learning by combining internal and external knowledge, receiving too much knowledge from other units may overburden subsidiary managers with knowledge that they cannot absorb. This may particularly be the case when subsidiary managers are cognitively focused on teaching others rather than learning themselves.

We expect that knowledge outflows will improve business performance up to a certain point, at which returns to increasing knowledge outflows begin to diminish and eventually become negative. Therefore, we propose a curve linear relationship (inverse U-shaped) between the outflow of knowledge and subsidiary performance, where increasing knowledge outflow will have a positive impact on performance up to a certain point. As soon as the amount of shared knowledge increases beyond this point the direct costs and opportunity costs will result in a negative relationship between knowledge outflow and performance. Accordingly, we expect:

H3. Knowledge outflows are first positively and then negatively related to a contributing subsidiary's performance (inverse U-shaped relationship).

\section{DATA AND METHOD}

The research was conducted in a German cement company, HeidelbergCement. With operations in more than 40 countries, worldwide sales of over 6 billion Euro and 38,000 employees, HeidelbergCement is one of the four largest cement manufacturers in the world. During our study, the company entered a consolidation phase following a rapid expansion. HeidelbergCement grew from less than 10,000 employees to its current size in less than ten 
years, mainly through acquisitions. One objective for the gradual integration of the newly acquired companies was to increase knowledge exchange between the different units.

Although using a one company sample has disadvantages in terms of the generalizability of results across sectors, it has advantages in terms of controlling for contextual factors that complicate the interpretation of results in multiple-firm samples (such as variations in industry and firm-specific factors). In addition, previous research has successfully used single firm sampling to explore the effects of intra-firm networks on resource exchange and combination (see Tsai and Ghoshal 1998). We decided to limit our survey to one company, which allows us to include more informants from each subsidiary. This is an advantage compared to most other studies that only include a single informant from each organization (typically the CEO) and treat the perception of this informant as representative of the whole organization (see Lane and Lubatkin 1998; Gupta and Govindarajan 2000).

We developed a questionnaire based on a literature review and 52 on-site interviews with senior managers of the 6 business units of HeidelbergCement. The interviews ranged from one to four hours in length. Ten senior managers were asked to complete the survey as a pilot run to increase the clarity of the questions and avoid interpretation errors. We discussed the face validity of the questions, which resulted in several substantial changes in the phrasing of the questions to avoid technical management terms. Following the survey pre-testing, we identified a sample of $265 \mathrm{MNC}$ unit managers stemming from all geographical business areas of HeidelbergCement. The selected managers represented three distinct groups: the first included 100 managers that had either been previously interviewed by our research team and/or participated in one of the international knowledge management workshops aiming at designing the HeidelbergCement knowledge management system. The second group consisted of 100 managers that had not been interviewed and did not participate in knowledge management 
workshops. The third group included 65 engineers from the subsidiaries who presented the views of the employees who are most directly involved in international day-to-day knowledge transfer.

The questionnaire was sent out in hard copy together with a six-page brochure explaining the scope of the knowledge management initiatives at HeidelbergCement as well as a letter from the CEO supporting the survey. Participants had four weeks to return the questionnaire via mail or fax. This mailing process was managed by headquarters, but respondents were assured of confidentiality and their identity was concealed. We collected 222 usable questionnaires, giving a response rate of $83.77 \%$.

The data was collected on the individual manager level although most of the survey questions referred to the subsidiary level, which in the case of HeidelbergCement is equal to an operational unit on the country level. We obtained responses from 20 different subsidiaries and got multiple responses from all subsidiaries except for one, requiring us to deal with the interrater reliability among respondents belonging to the same subsidiary.

\section{MEASURES}

All data were collected through the questionnaire and most variables are multi-item measures that were measured using seven-point Likert scales. However, items such as the number of employees were measured using actual values. The following sections provide information on the questionnaire items.

Financial performance. Several researchers have used perceptual measures of performance as opposed to more objective performance measures (such as return on equity), as objective measures mainly capture past performance (see Andersson et al. 2001). Perceptual measures have also shown a tendency to have a high correlation with objective accounting-based 
measures (Geringer and Hebert 1991). Accordingly, we apply a perceptual measure of performance, where respondents were asked to indicate their perception of the subsidiary's performance. Respondents indicated their perception of the two items revenues and cost savings using a Likert scale $(1=$ low, $7=$ very high). Financial performance was then calculated as the average score reported by respondents across these two items (Alpha=0.72).

Tacitness of knowledge. This construct expresses the level of tacitness of the knowledge in the focal subsidiary. Knowledge tacitness was measured by asking the respondents to assess to the following two statements "Large parts of knowledge in our unit are located in the heads of single individuals" and "Knowledge is extensively documented and well structured" (reverse coded) on a seven-point Likert scale (1=don't agree, $7=$ strongly agree). Tacitness was calculated as the average score for these two items (Alpha $=0.76$ ).

Communication channel. The construct captures the extent to which inexpensive and appropriate communication channels are in place for the transfer of knowledge to other MNC units. The assumption is that the face-to-face sharing of knowledge is the most simple transfer mechanism, but it is also very time consuming and requires intensive involvement on both ends (Pedersen et al. 2003). Therefore, on one end of the scale we have resource demanding face-toface transfer of knowledge and, on the other end, we have more routine and less demanding transfer mechanisms like intranets and databases. This construct was measured by asking respondents whether "Requesters contact us face to face" and "Requesters contact us via intranet or phone" (reverse coded) on a seven-point Likert scale (1=never, 7=always). The two items were added together and the average of the two items made up our communication channel construct (Alpha $=0.74)$.

Fear of opportunism. The construct fear of opportunism captures the extent to which the respondents fear that others will behave opportunistically when knowledge is transferred. The 
construct was measured by asking respondents to assess the following statement in terms of knowledge outflows to other MNC units: "I fear that they will steal our ideas" on a seven-point Likert scale (1=never, $7=$ =always $)$.

Acknowledgement of knowledge. The construct acknowledgement of knowledge captures the extent to which the focal subsidiary's knowledge is formally or informally acknowledged by other MNC units. This was measured by asking respondents to assess the extent to which "Knowledge represented in your unit is (formally/informally) acknowledged by other organizational units" on a seven-point Likert scale ( $1=$ not at all, $7=$ to a high degree). An average score was calculated for the two items (Alpha $=0.86)$.

Inflow of knowledge. The construct Inflow of knowledge captures the extent of knowledge inflow from other HeidelbergCement units to the focal unit. The construct was measured in line with other studies on knowledge flows in MNCs (Holm and Pedersen 2000) by asking respondents to assess to what extent knowledge represented in other units influences their work ( $1=$ not at all, $7=$ very strongly $)$.

Outflow of knowledge. This construct expresses the extent of outflow of knowledge from the focal unit to other units in HeidelbergCement. The construct was measured by asking respondents to assess to what extent knowledge represented in their units influences work in other units ( $1=$ not at all, $7=$ very strongly).

Both outflows and inflows of knowledge are measured as their influence on work in other units, which implies that knowledge is only fully shared when it is utilized and has an impact on another unit.

Controls. A number of control variables were added that are expected to have an impact on the outflow of knowledge as well as financial performance. One control variable is 
technological development, which is a binary variable expressing whether the particular subsidiary is involved in technological development (coded 1 if involved and 0 if not). We also control for others dependency, which is the extent to which other MNC units are dependent on the focal unit's knowledge (measured as a single item construct on a seven-point Likert scale where $1=$ not at all, $7=$ to a high degree). The assumption is that subsidiaries conducting technological development and/or subsidiaries on which other units depend for knowledge will have a potentially higher outflow of knowledge and be able to reap the benefits of knowledge outflows.

The potential personal bias among respondents is controlled for by adding a dummy variable indicating whether the respondent has been involved in the design of the Knowledge Management Program in HeidelbergCement, meaning that they have participated in the knowledge management workshops. Those involved in the design of the program may be more positive in their perception of knowledge management initiatives than others.

Since the data were collected on the individual manager level and since, on average, 11 managers responded for each subsidiary, we have the potential problem of interrater reliability. For example, the perception of subsidiary performance might vary between managers belonging to the same subsidiary. Therefore, we applied the Cohen's kappa statistics to the different measures. The Cohen's kappa statistics are designed to estimate the degree of consensus between managers belonging to the same subsidiary after correcting for the amount of agreement that could be expected by chance alone. Landis and Koch (1977) suggest that kappa values from 0.41-0.60 are moderate, and that values above 0.60 indicate a substantial degree of agreement. All the measures included in the models reached a kappa value above 0.60 except for the measure on opportunism, which has a kappa value of 0.48 . This is still acceptable and much higher than the level of agreement that could be expected by chance (kappa $=0)$. 
In order to control for the fact that some individual respondents are belonging to the same subsidiary, we added dummies for each subsidiary. The 222 usable observations represent 20 different subsidiaries. Since respondents from the same subsidiary obviously share the same organizational context, we cannot treat these observations as completely independent of each other. In order to control for this aspect, we have added a dummy for each subsidiary (except the base case $=$ Germany). Furthermore, as discussed by Delmestri and Walgenbach (2005), middle managers may play very different roles in the different countries in relation to knowledge processes. The different roles might affect the perception of the involved managers, which is another reason for including the subsidiary dummies to control for systematic biases in the perceptions of subsidiary managers.

\section{Results}

The hypotheses may be summarized in two equations as follows.

1) Outflow of knowledge $=f$ (Opportunism, Tacitness, Communication channels, Inflow of knowledge, Acknowledgement, Controls) + Error

2) Financial performance $=\boldsymbol{g}$ (Outflow of knowledge, Outflow of knowledge squared, Controls) + Error

As proposed in hypotheses $1 \mathrm{a}-1 \mathrm{c}$, we expect all the three impediments (opportunism, tacitness and communication channels) to be negatively related to the outflow of knowledge, while the two enablers (inflow of knowledge and acknowledgement) are expected to show a positive coefficient in equation 1 (hypotheses $2 \mathrm{a}$ and $2 \mathrm{~b}$ ). In order to test hypothesis 3 on the curve-linear relationship, we have added both the outflow of knowledge (first order) and the outflow of knowledge squared (second order), where the first order variable is expected to be 
positive and the second order variable expected to be negative with an inverse $U$ relationship between knowledge outflow and performance.

However, since the above models represent factors that are interdependent and must be considered jointly, the use of single equation models may yield biased results and obscure interesting theoretical possibilities. As the above equations are interdependent, the joint optimization of all involved variables may lead to the sub-optimization of one or more individual variables. Statistically, the interdependence might be evident if the error terms of the two equations are somehow correlated. Hence, the correct model to estimate these decisions is a simultaneous equation model -- a three-stage, least square model circumvents the problem of interdependence by using instrumental variables (often the exogenous variables) to obtain the predicted values of the endogenous variables (knowledge outflow and financial performance in our case).

The correlation matrix (including all correlation coefficients) and the descriptive data (mean values, standard deviation, minimum and maximum values) for all variables in the model are provided by Appendix 1. In order to detect potential problems of multicollinearity, we should look at correlation coefficients among the model's independent variables. None of these are above the threshold that usually indicates the possibility of multicollinearity ( $r>0.5$ ), (Hair et al. 1995). Therefore, we conclude that the results are very stable in terms of the different specifications of the model and that the data does not seem to include problems of multicollinearity.

We have applied the three-stage least square regression techniques (3SLS) with instrumental variables to test all hypotheses simultaneously. The result of the total model is given in Table 1, where the numbers in parentheses represent standard errors. 
Overall, the system of the two equations (models) works well, with a system weighted Rsquare of 0.44 . This indicates that almost half of the observed variation in the contributing subsidiary's performance is explained by the variables in the model.

The Hausman test (comparing the OLS model with the 3SLS model) confirms that our specification of knowledge outflow and subsidiary performance as endogenously determined (3SLS) is superior to the OLS model. In fact, the value of the Hausman specification test comparing the OLS and 3SLS of $43.31(p<0.001)$ indicates that the model where the level of knowledge outflow is determined endogenously (by the enablers and impediments) gives far better estimates for knowledge outflows and subsidiary performance than two separate OLS models. This gives further evidence to the claim that the level of knowledge outflows cannot be assumed to be an exogenous variable, but needs to be determined endogenously in the model.

\section{**** Insert Table 1 about here $* * * *$}

As shown in Table 1 , the two impediments of knowledge tacitness $(\mathrm{p}<0.10)$ and communication channels $(p<0.01)$ have a significantly negative impact on the outflow of knowledge from the focal unit. However, the fear of opportunism has the expected negative coefficient, but is insignificant. The results indicate that the main impediments associated with the outflow of knowledge are those required to establish appropriate communication channels and codify knowledge, while fear of opportunism is of minor importance among MNC units.

Both enablers have, as expected, positive coefficients and are highly significant. With a coefficient of 0.46 , the inflow of knowledge $(p<0.01)$ is a particular strong facilitator of knowledge outflow, which indicates that knowledge flows are a reciprocal game to a large extent. A subsidiary's own knowledge is shared with the expectation that it will then have access 
to another unit's knowledge. The same is true for the acknowledgement of knowledge $(p<0.05)$, which positively facilitates the outflow of knowledge, but to a lesser extent. The results indicate that the benefits of transferring knowledge to other units are related to reputation and appreciation (acknowledgement), and to obtaining access to continuous knowledge sharing. These are more positional advantages, reflecting the focal subsidiary's position within the knowledge sharing network.

Furthermore, as expected, the outflow of knowledge has a strong positive impact $(\mathrm{p}<$ 0.01 ) on the financial performance of the subsidiary. However, the positive impact only lasts to a certain point indicated by the negative impact of outflow of knowledge squared. This result strongly supports hypothesis 3 that an inverse U-shaped relationship exists between knowledge outflow and performance. The implication is that for low levels of knowledge outflow, knowledge sharing with other units improves the focal unit's financial performance. At a certain point, however, the marginal costs of further knowledge sharing increase and the benefits diminish so that knowledge sharing has a negative impact on performance. These results remain the same when controlling for technological development, dependency on others, involvement in design and subsidiary dummies (the two first turned out to be significant in themselves).

The advantage of the model is that it establishes a link between the decision to engaging in knowledge outflows and the performance outcome of different levels of knowledge sharing. By doing that we have been able to identify the drivers of knowledge sharing among subsidiaries which is rarely discussed in the literature and to point out that knowledge sharing may not always be beneficial for the contributing subsidiary.

\section{DISCUSSION}


Why do MNC subsidiaries engage in knowledge sharing with other subsidiaries and what are the implications for performance? This research suggests that a subsidiary's willingness to engage in knowledge outflow depends on enablers of as well as impediments to knowledge outflows. The main impediments are lack of appropriate communication channels and, to a lesser extent, the tacitness of knowledge, while the main enablers are the reciprocal inflow of knowledge and the acknowledgement of unique subsidiary knowledge. Our research shows a significant inverse U-shape relation between knowledge outflows and performance, indicating that subsidiaries may increase performance by increasing knowledge outflows until a point is reached where increasing marginal costs and diminishing benefits indicate a performance penalty for subsidiaries, which share more knowledge than is good for their performance.

A self-interested subsidiary within the MNC shares knowledge with other units to the extent that it expects benefits greater than costs. Engaging in knowledge outflows allows a subsidiary to receive reciprocal knowledge inflows from other units that, if effectively applied, contribute to the focal subsidiary's performance. This research finds that knowledge inflows significantly affect knowledge outflows both because knowledge inflows are an input for knowledge outflows and because the subsidiaries are engaged in a reciprocal game where knowledge providers gain knowledge from other MNC units. In addition, MNC headquarters' acknowledgement of valuable subsidiary knowledge significantly increases the subsidiary's propensity to share knowledge with other units. Reputation gained might also contribute to a subsidiary's participation in knowledge sharing as it can aid in lobbying decision makers and acquiring favorable positions in the MNC's fund allocation process. Our results also suggest that tacitness of knowledge and lack of access to appropriate communication channels act as disincentives knowledge sharing among self-interested subsidiaries. Thus, our findings support prior research on determinants of MNC internal knowledge flows (Tsai and Ghoshal 1998, Gupta 
and Govindarajan 2000; Minbaeva et al. 2003; Foss and Pedersen 2003) and extend this stream of research by focusing on the perspective of the contributing subsidiary.

These results make a significant contribution to current research on subsidiary knowledge sharing behavior, given that improving business performance is one of the most important objectives for subsidiaries in large, complex organizations such as an MNC. We show that knowledge outflows are not only in the interest of the $\mathrm{MNC}$ as a whole, but also benefit the selfinterested subsidiary. While prior studies have restricted their analyses to antecedents of knowledge flows in terms of shared knowledge and neglected the performance implications, this paper contributes a direct test of the performance implications of knowledge outflows. With regard to methodology, a unique data set encompassing individual perceptions of knowledge processes from one $\mathrm{MNC}$ - HeidelbergCement - is applied to test the entire model, including antecedents (enablers and impediments), the intermediary steps (knowledge outflows) and the final outcome (subsidiary performance). This research shows that knowledge outflows significantly affect a subsidiary's performance, as indicated by the inverted U-shape.

This finding is interesting given that previous research has focused on the effect of antecedents to knowledge outflows without addressing how increased levels of knowledge outflows influence subsidiary performance. A central assumption of knowledge sharing research is that increased knowledge sharing benefits the MNC as a whole (see Gupta and Govindarajan 2000). However, our findings indicate an inverse U-shaped relation between knowledge outflow and subsidiary performance. We have explained this finding with reference to (a) decreasing benefits and increasing costs of knowledge sharing while creating more appropriate communication channels and codifying knowledge to make higher levels of knowledge outflows possible, and (b) diminishing returns to increasing levels of knowledge inflows that cannot be absorbed (see Tsai and Ghoshal 1998). Other explanations may be possible. Thus, future 
research may investigate the U-shaped relation between performance and subsidiary knowledge outflows by empirically addressing alternative reasons.

Our findings on the knowledge outflow/performance relation raise a red flag with regard to the assumption that knowledge sharing is always beneficial for the subsidiary and the MNC as a whole. As soon as knowledge outflows from a focal subsidiary exceed a certain point, the subsidiary incurs performance penalties. By implication, for the "more knowledge sharing is good" assumption to hold at the MNC level, the benefits of knowledge inflows in other subsidiaries must overcompensate for performance penalties incurred by contributing subsidiaries that share too much knowledge. Increasing the level of knowledge sharing can be detrimental to performance on both the subsidiary and MNC levels. Although previous research indicated how to increase levels of shared knowledge by removing impediments to knowledge sharing (see Szulanski 2003; Michailova and Husted 2003), there is little systematic understanding of how to optimize levels of knowledge sharing with regards to increasing performance on both the subsidiary and MNC levels. Future studies could further explore this issue.

Interesting results may also arise from an examination of why self-interested subsidiaries share more knowledge than is good for their performance. Our findings indicate that subsidiaries increase knowledge outflows in response to perceived dependence on other subsidiaries. Thus, despite possible negative effects on the subsidiary's performance, a subsidiary's knowledge sharing might be motivated by attempts to signal good citizen behavior and to comply with knowledge sharing norms. Another interesting explanation that could be addressed in future research relates to the career-seeking behavior of subsidiary managers who share knowledge to increase their personal reputation at the cost of their subsidiary's performance. Future research 
pursuing this line of inquiry has the potential to make significant contributions to management research in general and to research on knowledge processes in the MNC in particular. 


\section{References}

Andersson U, M. Forsgren and U. Holm

2002 The strategic impact of external networks: Subsidiary performance and competence development in the multinational corporation. Strategic Management Journal 23/11: 979998

Andersson U, M. Forsgren and T. Pedersen

2001 'Subsidiary performance in multinational corporations: the importance of technology embeddedness'. International Business Review 10/1: 3-23

Asakawa K.

2001 'Organizational tensions in international R\&D management: The case of Japanese firms'. Research Policy 30/5: 735-757.

Asakawa, K and M. Lehrer

2003 'Managing local knowledge assets globally: the role of regional innovation relays'. Journal of World Business, 38/1: 31-42.

Bartlett CA. and S. Ghoshal

1989 Managing across Borders. The Transnational Solution. Harvard Business School Press: Cambridge, MA.

Birkinshaw JM. and AJ. Morrison

1995 'Configurations of Strategy and Structure in Multinational Subsidiaries'. Journal of International Business Studies 26/4: 729-54. 
Cabrera, A. and EF. Cabrera

2002 'Knowledge-sharing Dilemmas'. Organization Studies 23/5: 687-710.

Cohen R and D. Foray

1997 'The Economics of Codification and the Diffusion of Knowledge'. Industrial and Corporate Change 67/4: 595-622.

Cohen W and D. Levinthal

1990 'Absorptive Capacity: A New perspective on Learning and Innovation'. Administrative Science Quarterly 35/1: 128 - 152.

Daft RL and RH. Lengel

1986 'Organizational Information Requirements, Media Richness and Structural Design'. Management Science 32/5: 554-571.

Delmestri G. and P. Walgenbach

2005 'Mastering Techniques or Brokering Knowledge? Middle Managers in Germany, Great Britain and Italy'. Organization Studies 26/2: 197-220.

Ferner, A., P. Almond, I. Clark, T. Colling, T. Edwards, L. Holden and M. Muller-Carmen

2004 'The Dynamics of Central Control and Subsidiary Autonomy in the Management of Human Resources: Case-Study Evidence from US MNCs in the UK'. Organization Studies 25/3: 363-391.

Forsgren $M$. 
1997 The Advantage Paradox of the Multinational Corporation. In I Björkman M Forsgren (Eds.), The Nature of the International Firm. Copenhagen Business School Press.

Forsgren M, J. Johanson and D. Sharma

2002 Development of MNC centres of excellence. In U Holm, T Pedersen (Eds.). Centres of Excellence. McMillan.

Foss N.

2003 'Selective Intervention and Internal Hybrids: Interpreting and Learning from the Rise and Decline of the Oticon Spaghetti Organization'. Organization Science 14/3: 331-349.

Foss N and V. Mahnke

2003 Knowledge management: What can organizational economics contribute? In M Lyles, M Esterby (Eds.), Handbook of Organizational Learning and Knowledge Management. Blackwell Publisher.

Foss N and T. Pedersen

2002 'Transferring Knowledge in MNCs: The Roles of Sources of Subsidiary Knowledge and Organizational Context'. Journal of International Management 8: 1-19.

Frey B.

1997 Not just for money. A Personal Theory of Motivation. Edward Elgar.

Frost TS.

2001 'The geographic sources of foreign subsidiaries' innovations'. Strategic Management Journal 22/2: 101-123. 
Geringer JM. and L. Hebert

1991 'Measuring performance of international joint ventures'. Journal of International Business Studies 22/2: 249-263.

Ghoshal S, H. Korine and G. Szulanski

1994' Interunit communication in multinational corporations'. Management Science 40/1: 96111.

Gupta AK and V. Govindarajan

1991 'Knowledge Flows and the Structure of Control within Multinational Corporations'. Academy of Management Review 16/4: 768-792.

Gupta AK and V. Govindarajan

2000 'Knowledge Flows Within Multinational Corporations'. Strategic Management Journal 21/4: 473-496.

Hair JF, RE. Anderson, RL. Tatham and WC. Black

1995 Multivariate Data Analysis. New Jersey: Prentice Hall.

Hansen MT.

1999 'The search transfer problem: The role of weak ties in sharing knowledge across organizational subunits'. Administrative Science Quarterly 44/1: 82-111.

Holm U and T. Pedersen

2000 The Emergence and Impact of MNC Centres of Excellence. Macmillan Press: London.

Holmstrom B. 
1979 'Moral hazard and observability'. Bell Journal of Economics 10/1: 74-91.

Kim WC and R. Mauborgne

1998 'Procedural justice, strategic decision making, and the knowledge economy'. Strategic Management Journal 19/4: 323-338.

Kogut B and U. Zander

1992 'Knowledge of the Firm, Combinative Capabilities, and the Replication of Technology'. Organization Science 3/3: 383-397.

Kogut B and U. Zander

1993. 'Knowledge of the Firm and the Evolutionary Theory of the Multinational Corporation'. Journal of International Business Studies 24/4: 625-645.

\section{Kreps D.}

1990 Corporate culture and economic theory. In J Alt, K Shepsle (Eds.), Perspectives on positive political economy: 90-143. Cambridge University Press: New York.

Kuemmerle W.

1999 'Foreign direct investment in industrial research in the pharmaceutical industry --- results from a survey of multinational firms'. Research Policy 28/2-3: 179-193.

Lagerstrom, K. and M. Andersson

2003 'Creating and sharing knowledge within a transnational team--the development of a global business system'. Journal of World Business, 38/2: 84-95.

Landis, J.R. and GG. Koch 
1977 'The measurement of observer agreement for categorial data'. Biometrics, 33/1: 159-174

Lane PJ. and M. Lubatkin

1998 'Relative Absorptive Capacity and Inter-Organizational Learning'. Strategic Management Journal 19/8: 461-477.

Laursen K and V. Mahnke

2001 'Knowledge strategies, innovative capacity and complementarity in human resource practices'. Journal of Management and Governance 5/1: 1-27.

Lunnan, R. and T. Barth

2003 'Managing the exploration vs. exploitation dilemma in transnational "bridging teams"'. Journal of World Business, 38/2: 110-126.

Mahnke V, T. Pedersen and M. Venzin

2005 'The Impact of Knowledge Management on MNC Subsidiary Performance: The Role of Absorptive Capacity' Management International Review, Special Issue (2): 101-119..

Mahnke V and M. Venzin

2003 'Governing knowledge teams in the MNC'. Management International Review, 43/3: 23 47.

Michailova, S. and K. Husted.

2003 'Knowledge-sharing hostility in Russian firms'. California Management Review 45/3: 5977.

Minbaeva D, T. Pedersen, I. Björkman, C. Fey and HJ. Park 
2003 'MNC Knowledge Transfer, Subsidiary Absorptive Capacity and HRM'. Journal of International Business Studies 34/6: 586-599.

Milgrom P and J. Roberts

1988 'An economic approach to influence activities and organizational responses'. American Journal of Sociology. 94: 154-179 (Supplement).

Milgrom P and J. Roberts

1990 Bargaining costs, influence costs and the organization of economic activity. In JE Alt, KA Shepsle (Eds.), Perspectives on Positive Political Economy: 57-89. Cambridge University Press: Cambridge.

Mudambi R. and P. Navarra

2004 'Is Knowledge Power? Knowledge Flows, Subsidiary Power and rent-seeking within MNCs'. Journal of International Business Studies, 35/5: 385-406 (forthcoming).

Nonaka I and H. Takeuchi

1995 The Knowledge Creating Company. Oxford University Press: Oxford

Ouchi WG.

1982 'Markets, Bureaucracies, and Clans'. Administrative Science Quarterly 25/1: 129-141.

Pedersen T, B. Petersen and D. Sharma

2003 'Knowledge Transfer Performance of Multinational Companies'. Management International Review, special issue 3: 69-90.

Polanyi M. 
1966 The Tacit Dimension. Routledge \& Kegan Paul: London

Rugman AM. and A. Verbeke

1992 'A note on the transnational solution and the transaction cost theory of multinational strategic management'. Journal of International Business Studies 23/4: 761-771.

Simonin BL.

1999 'Transfer of Marketing Know-How in International Strategic Alliances: an Empirical Investigation of the Role and Antecedents of Knowledge Ambiguity'. Journal of International Business Studies 30/3: 463-490.

Szulanski G.

1996 'Exploring Internal Stickiness: Impediments to the Transfer of Best Practice within the Firm'. Strategic Management Journal, special issue, 17: 27-43.

Szulanski G.

2003 Sticky Knowledge. Barriers to Knowing in the FirmKnowledge Stickiness. London: Sage.

Tsai W. and S. Ghoshal

1998 'Social capital and value creation: The role of intrafirm networks'. Academy of Management Journal 41/4: 464-477.

von Hippel E. and MJ. Tyre

1994 How learning by doing is done: Problem identification in novel process equipment. Research Policy 24/1: 1-12.

Werr A. and T. Stjernberg 
2003 Exploring Management Consulting Firms as Knowledge Systems. Organization Studies 24/6: 881-908.

Williamson OE.

1975 Markets and Hierarchies: Analysis and Antitrust Implications. Free Press: New York.

Williamson OE.

1996 The mechanism of governance. Oxford University Press

Zahra SA. and G. George

2002 Absorptive Capacity: a review, reconceptualization, and extension. Academy of Management Review 27/2: 185-203.

Zollo M. and SG. Winter

2002 Deliberate learning and the evolution of dynamic capabilities. Organization Science 13/3: $339-351$. 
Table 1: The three-stage least squares estimation of a simultaneous equation model $(\mathrm{N}=222)$.

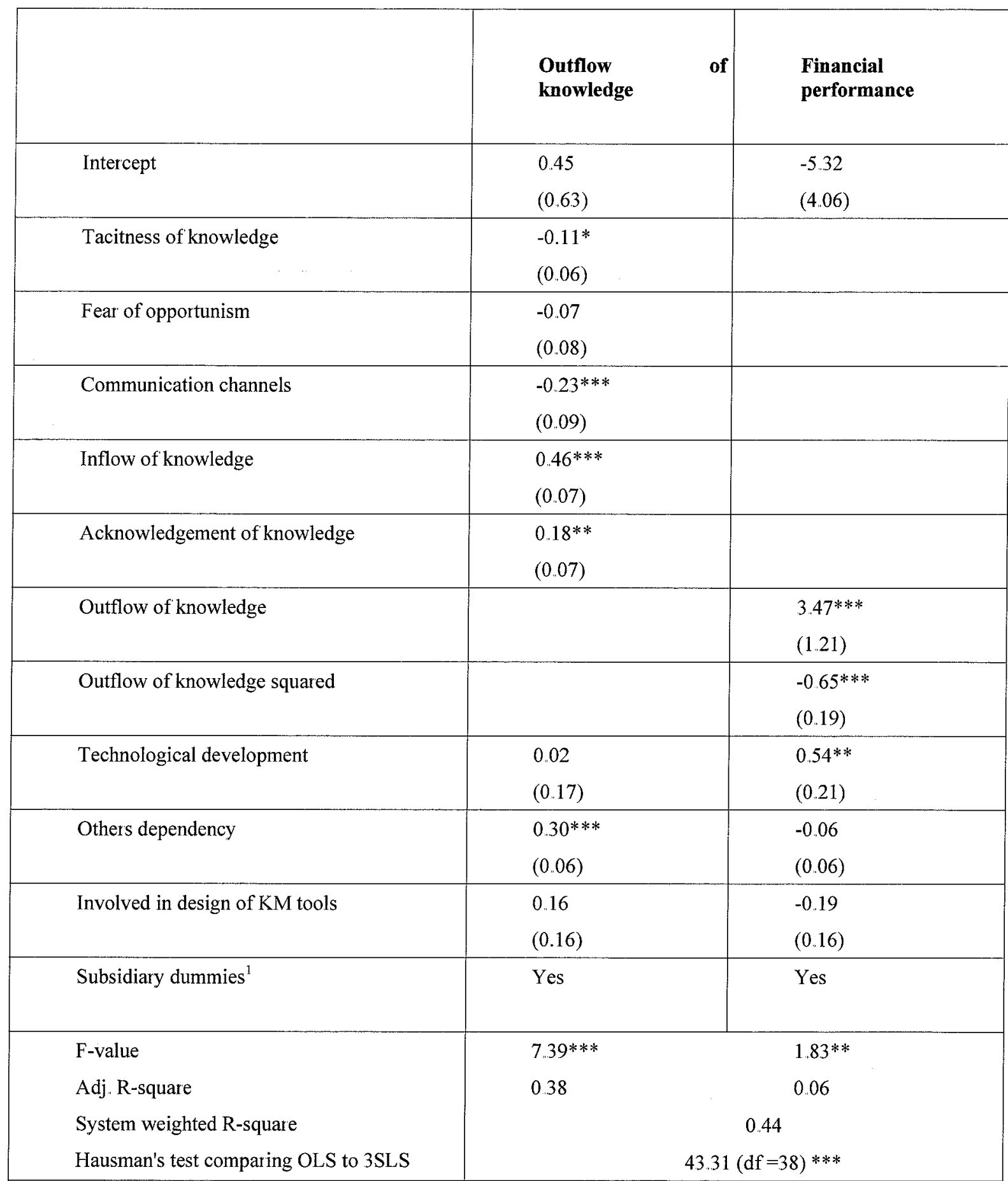

$* * *,{ }^{* *}$ and ${ }^{*}=$ significant at 1,5 and 10 percent, respectively. ${ }^{1}$ The model includes 20 dummies - one for each subsidiary, however, the parameters are not shown 


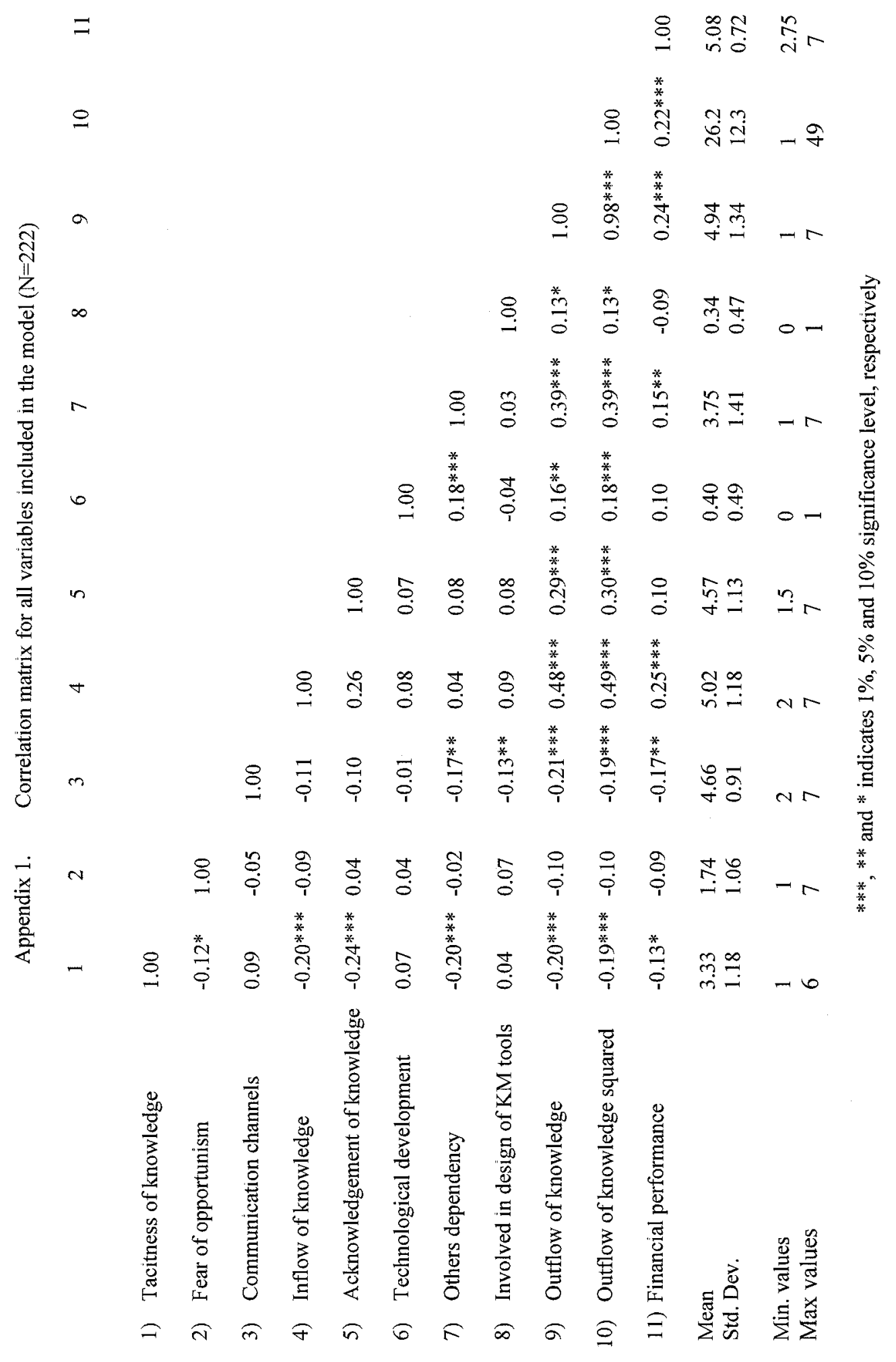





\section{SMG - Working Papers \\ www.cbs.dk/smg \\ 2003}

2003-1: Nicolai J. Foss, Kenneth Husted, Snejina Michailova, and Torben Pedersen: Governing Knowledge Processes: Theoretical Foundations and Research Opportunities.

2003-2: Yves Doz, Nicolai J. Foss, Stefanie Lenway, Marjorie Lyles, Silvia Massini, Thomas P. Murtha and Torben Pedersen: Future Frontiers in International Management Research: Innovation, Knowledge Creation, and Change in Multinational Companies.

2003-3: Snejina Michailova and Kate Hutchings: The Impact of In-Groups and OutGroups on Knowledge Sharing in Russia and China CKG Working Paper.

2003-4: Nicolai J. Foss and Torben Pedersen : The MNC as a Knowledge Structure: The Roles of Knowledge Sources and Organizational Instruments in MNC Knowledge Management CKG Working Paper.

2003-5: Kirsten Foss, Nicolai J. Foss and Xosé H. Vázquez-Vicente: “Tying the Manager's Hands": How Firms Can Make Credible Commitments That Make Opportunistic Managerial Intervention Less Likely CKG Working Paper.

2003-6: Marjorie Lyles, Torben Pedersen and Bent Petersen: Knowledge Gaps: The Case of Knowledge about Foreign Entry.

2003-7: Kirsten Foss and Nicolai J. Foss: The Limits to Designed Orders: Authority under "Distributed Knowledge" CKG Working Paper.

2003-8: Jens Gammelgaard and Torben Pedersen: Internal versus External Knowledge Sourcing of Subsidiaries - An Organizational Trade-Off.

2003-9: Kate Hutchings and Snejina Michailova: Facilitating Knowledge Sharing in Russian and Chinese Subsidiaries: The Importance of Groups and Personal Networks Accepted for publication in Journal of Knowledge Management.

2003-10: Volker Mahnke, Torben Pedersen and Markus Verzin: The impact of knowledge management on MNC subsidiary performance: the role of absorptive capacity CKG Working Paper.

2003-11: Tomas Hellström and Kenneth Husted: Mapping Knowledge and Intellectual Capital in Academic Environments: A Focus Group Study Accepted for publication in Journal of Intellectual Capital CKG Working Paper.

2003-12: Nicolai J Foss: Cognition and Motivation in the Theory of the Firm: Interaction or "Never the Twain Shall Meet"? Accepted for publication in Journal des Economistes et des Etudes Humaines CKG Working Paper.

2003-13: Dana Minbaeva and Snejina Michailova: Knowledge transfer and expatriation practices in MNCs: The role of disseminative capacity.

2003-14: Christian Vintergaard and Kenneth Husted: Enhancing selective capacity through venture bases. 


\section{4}

2004-1: Nicolai J. Foss: Knowledge and Organization in the Theory of the Multinational Corporation: Some Foundational Issues

2004-2: Dana B. Minbaeva: HRM practices and MNC knowledge transfer

2004-3: Bo Bernhard Nielsen and Snejina Michailova: Toward a phase-model of global knowledge management systems in multinational corporations

2004-4: Kirsten Foss \& Nicolai J Foss: The Next Step in the Evolution of the RBV: Integration with Transaction Cost Economics

2004-5: Teppo Felin \& Nicolai J. Foss: Methodological Individualism and the Organizational Capabilities Approach

2004-6: Jens Gammelgaard, Kenneth Husted, Snejina Michailova: Knowledge-sharing Behavior and Post-acquisition Integration Failure

2004-7: Jens Gammelgaard: Multinational Exploration of Acquired R\&D Activities

2004-8: Christoph Dörrenbächer \& Jens Gammelgaard: Subsidiary Upgrading? Strategic Inertia in the Development of German-owned Subsidiaries in Hungary

2004-9: Kirsten Foss \& Nicolai J. Foss: Resources and Transaction Costs: How the Economics of Property Rights Furthers the Resource-based View

2004-10: Jens Gammelgaard \& Thomas Ritter: The Knowledge Retrieval Matrix: Codification and Personification as Separate Strategies

2004-11: Nicolai J. Foss \& Peter G. Klein: Entrepreneurship and the Economic Theory of the Firm: Any Gains from Trade?

2004-12: Akshey Gupta \& Snejina Michailova: Knowledge Sharing in Knowledge-Intensive Firms: Opportunities and Limitations of Knowledge Codification

2004-13: Snejina Michailova \& Kate Hutchings: Knowledge Sharing and National Culture: A Comparison Between China and Russia

\section{5}

2005-1: Keld Laursen \& Ammon Salter: My Precious - The Role of Appropriability Strategies in Shaping Innovative Performance

2005-2: Nicolai J. Foss \& Peter G. Klein: The Theory of the Firm and Its Critics: A Stocktaking and Assessment

2005-3: Lars Bo Jeppesen \& Lars Frederiksen: Why Firm-Established User Communities Work for Innovation: The Personal Attributes of Innovative Users in the Case of Computer-Controlled Music

2005-4: Dana B. Minbaeva: Negative Impact of Hrm Complementarity on Knowledge Transfer in Mncs

2005-5: Kirsten Foss, Nicolai J. Foss, Peter G. Klein \& Sandra K. Klein: Austrian Capital Theory and the Link Between Entrepreneurship and the Theory of the Firm 
2005-1: Nicolai J. Foss: The Knowledge Governance Approach

2005-2: Torben J. Andersen: Capital Structure, Environmental Dynamism, Innovation Strategy, and Strategic Risk Management

2005-3: Torben J. Andersen: A Strategic Risk Management Framework for Multinational Enterprise

2005-4: Peter Holdt Christensen: Facilitating Knowledge Sharing: A Conceptual Framework

2005-5 Kirsten Foss \& Nicolai J. Foss: Hands Off! How Organizational Design Can Make Delegation Credible

2005-6 Marjorie A. Lyles, Torben Pedersen \& Bent Petersen: Closing the Knowledge Gap in Foreign Markets - A Learning Perspective

2005-7 Christian Geisler Asmussen, Torben Pedersen \& Bent Petersen: How do we capture "Global Specialization" when measuring firms' degree of internationalization?

2005-8 Kirsten Foss \& Nicolai J. Foss: Simon on Problem-Solving: Implications for New Organizational Forms

2005-9 Birgitte Grøgaard, Carmine Gioia \& Gabriel R.G. Benito: An Empirical Investigation of the Role of Industry Factors in the Internationalization Patterns of Firms

2005-10 Torben J. Andersen: The Performance and Risk Management Implications of Multinationality: An Industry Perspective

2005-11 Nicolai J. Foss: The Scientific Progress in Strategic Management: The case of the Resource-based view

2005-12 Koen H. Heimeriks: Alliance capability as a mediator between experience and alliance performance: An empirical investigation into the alliance capability development process

2005-13 Koen H. Heimeriks, Geert Duysters \& Wim Vanhaverbeke: Developing Alliance Capabilities: An Empirical Study

2005-14 JC Spender: Management, Rational or Creative? A Knowledge-Based Discussion

\section{6}

2006-1: Nicolai J. Foss \& Peter G. Klein: The Emergence of the Modern Theory of the Firm

2006-2: Teppo Felin \& Nicolai J. Foss: Individuals and Organizations: Thoughts on a Micro-Foundations Project for Strategic Management and Organizational Analysis

2006-3: Volker Mahnke, Torben Pedersen \& Markus Venzin: Does Knowledge Sharing Pay? An MNC Subsidiary Perspective on Knowledge Outflows 